\title{
Emergency contraception: knowledge, attitude and practices among women in South Delhi, India
}

\author{
Ayesha Ahmad, Aruna Nigam*, Arifa A. Elahi, Reena Jain, Swaraj Batra
}

Department of Obstetrics and Gynaecology, Hamdard Institute of Medical Sciences and Research, New Delhi 110001, India

Received: 06 December 2015

Accepted: 07 January 2016

\section{*Correspondence:}

Dr. Aruna Nigam,

E-mail: prakasharuna@hotmail.com

Copyright: (C) the author(s), publisher and licensee Medip Academy. This is an open-access article distributed under the terms of the Creative Commons Attribution Non-Commercial License, which permits unrestricted non-commercial use, distribution, and reproduction in any medium, provided the original work is properly cited.

\begin{abstract}
Background: Objective of the study was to assess the awareness of emergency contraception (EC) amongst women attending the routine antenatal outpatient services.

Methods: It was a hospital based cross sectional study for one year. 550 women were enrolled in the study after written informed consent. Socio demographic characteristics, knowledge, attitude and practice towards EC were analyzed.

Results: Majority of the women were between 20 to 29 years, and had a basic level of education. $60.4 \%$ women were housewives, and $70.5 \%$ of them had an urban place of residence. 94\% women knew about some method of contraception. Only 34.5\% women knew EC; amongst them 54.2\% knew about EC pills and $12.5 \%$ had used it at least once. $40.5 \%$ women knew that there are methods of EC but did not know how what these methods were. $67.9 \%$ of women did not know how long after unprotected intercourse EC should be taken.

Conclusions: Majority of the women were between 20 to 29 years, and had a basic level of education. 60.4\% women were housewives, and $70.5 \%$ of them had an urban place of residence. 94\% women knew about some method of contraception. Only 34.5\% women knew EC; amongst them $54.2 \%$ knew about EC pills and $12.5 \%$ had used it at least once. $40.5 \%$ women knew that there are methods of EC but did not know how what these methods were. $67.9 \%$ of women did not know how long after unprotected intercourse EC should be taken.
\end{abstract}

Keywords: Contraception, Emergency contraception, Family planning

\section{INTRODUCTION}

Global statistics estimate that two out of every five pregnancies are unintended. ${ }^{1}$ The situation is more poignant in developing countries where as many as one third of all pregnancies are unintended. Among these, $19 \%$ undergo induced abortion [57.9\% undergo unsafe abortion]. ${ }^{2}$ Emergency contraception (EC) gains significance in this regard as it has the potential to reduce unintended pregnancy rate due to unprotected intercourse. EC is described as a device or drug used as an emergency procedure to prevent pregnancy. ${ }^{2}$ Common reasons for procurement of EC remain condom breakage, failure to use condom and missed oral contraceptive pills. $^{3}$

The present study seeks to explore the knowledge and awareness of EC in a select population in Delhi.

\section{Aim of the study}

To assess the awareness of EC amongst women attending the routine antenatal outpatient services at $\mathrm{HAH}$ Centenary Hospital. 


\section{METHODS}

This is a cross sectional study conducted over a period of one year at HAH Centenary Hospital. Prior approval was taken by the institutional ethical committee. The study was questionnaire based, using a structured pre-validated questionnaire with both open ended and close ended questions. Patient confidentiality was ensured.

\section{Inclusion criteria}

All women attending antenatal outpatient services at the hospital and willing to participate in the study and comply with the documentary formalities were included.

\section{Exclusion criteria}

Women who were not antenatal or those who declined to be a part of the study were not included.

A total of 550 women gave informed consent and were recruited for the study. Information was collected on demographic characteristics like age, parity, literacy status, and religion and socio economic status. Questions to assess knowledge of contraception and awareness of EC were asked in detail.

\section{RESULTS}

The socio demographic characteristics of the study population are depicted in Table 1 . Most of the women were in the age bracket of 20 to 29 years [75.1\%]. Only a minority of women were illiterate [7.6\%] with the others having received at least basic schooling or beyond. $36.7 \%$ women had completed tenth standard. $60.4 \%$ women were not working and most of them had an urban place of residence [70.5\%]. Maximum women belonged to Hindu community [70.5\%], followed by Muslims [26.2\%], Sikhs [2.9\%] and Christians [0.4\%]. Most of the subjects were from upper middle or middle class, and had a parity of one or two.

Table 2 depicts the knowledge of contraception in the study population. $94 \%$ women were aware about some method of contraception. Male condom, natural methods and oral contraceptive pills were the most common methods known to the women. Awareness regarding injectable contraception was least among all methods. $67.8 \%$ of women claimed usage of male condom by partner at least once. $56.4 \%$ women had used natural methods. The information regarding contraception had been disseminated mostly by friends, relatives or social media. $45.8 \%$ women had also received information from medical personnel.

Knowledge of EC is shown in Table 3. Majority [65.5\%] women had no knowledge of EC. $34.5 \%$ women knew EC; amongst them $54.2 \%$ knew about EC pills and $12.5 \%$ had used it at least once. $40.5 \%$ women knew that there are methods of EC but did not know how what these methods were. Some women believed that male condom was a method of EC [4.7\%]. Majority of women [67.9\%] did not know how long after unprotected intercourse EC should be taken.

Table 1: Demographic profile.

\begin{tabular}{|c|c|c|}
\hline Population characteristic & $\mathrm{N}=550$ & $\%$ \\
\hline \multicolumn{3}{|l|}{ Age [in years] } \\
\hline Less than 20 & 23 & 4.2 \\
\hline $20-29$ & 413 & 75.1 \\
\hline$>30$ & 114 & 20.7 \\
\hline \multicolumn{3}{|l|}{ Literacy status of woman } \\
\hline Illiterate & 42 & 7.6 \\
\hline Basic schooling & 74 & 13.5 \\
\hline High school & 202 & 36.7 \\
\hline Senior secondary & 99 & 18.0 \\
\hline Graduate & 89 & 16.2 \\
\hline Post graduate & 44 & 8 \\
\hline \multicolumn{3}{|l|}{ Occupation } \\
\hline Non working & 332 & 60.4 \\
\hline Working & 218 & 39.6 \\
\hline \multicolumn{3}{|l|}{ Place of Residence } \\
\hline Rural & 162 & 29.5 \\
\hline Urban & 388 & 70.5 \\
\hline \multicolumn{3}{|l|}{ Religion } \\
\hline Hindu & 388 & 70.5 \\
\hline Muslim & 144 & 26.2 \\
\hline Sikh & 16 & 2.9 \\
\hline Christian & 02 & 0.4 \\
\hline \multicolumn{3}{|l|}{ Socio economic class } \\
\hline Upper & $\begin{array}{l}60 \\
203\end{array}$ & $\begin{array}{l}10.9 \\
36.9\end{array}$ \\
\hline Upper middle & $\begin{array}{l}203 \\
195\end{array}$ & 35.5 \\
\hline Middle & 80 & 14.5 \\
\hline $\begin{array}{l}\text { Lower middle } \\
\text { Lower }\end{array}$ & 12 & 2.2 \\
\hline \multicolumn{3}{|l|}{ Parity } \\
\hline Para 1 & 243 & 44.2 \\
\hline Para 2 & 186 & 33.8 \\
\hline Para 3 & 87 & 15.8 \\
\hline Para 4 & 22 & 04.0 \\
\hline Parity more than 4 & 12 & 02.2 \\
\hline
\end{tabular}

\section{DISCUSSION}

According to NFHS-III, knowledge about various temporary and permanent methods of contraception ranges from $45 \%$ to $97 \%$ in India. We found that our study population had good knowledge of contraceptive methods [94\%]. Knowledge about EC in India is around $20 \%$ in men and $11 \%$ in women. ${ }^{4}$ We observed awareness of EC was much higher than the national average [34.5\%] although this was also low. A study from the Bengal on 100 women from immunization clinic the knowledge of EC was found to be $59.2 \% .^{5}$ This may be a reflection of the majorly urban residence of the subjects. A multi country analysis observed that in India $0.2 \%$ women, in France $17 \%$ and in United States $11 \%$ 
women between 15-44 years used EC. ${ }^{6}$ We noted that $12.5 \%$ of our study population has used EC which is much above the national average, reason being the urban population and the national capital region.

Table 2: Knowledge of contraception.

\begin{tabular}{|ll|ll|}
\hline Question & Answer & N & $\%$ \\
\hline $\begin{array}{l}\text { Do you have } \\
\text { any knowledge } \\
\text { of contraception }\end{array}$ & Yes & 517 & 94 \\
\cline { 2 - 4 } & No & 33 & 6 \\
\hline \multirow{4}{*}{$\begin{array}{l}\text { Which type of } \\
\text { contraception } \\
\text { do you know }\end{array}$} & Natural & 386 & 70.2 \\
\cline { 2 - 4 } & Oral condraceptive & 489 & 88.9 \\
\cline { 2 - 4 } & IUlls & 334 & 60.7 \\
\cline { 2 - 4 } & Injectable & 267 & 48.5 \\
\hline \multirow{3}{*}{$\begin{array}{l}\text { Which method } \\
\text { have you used }\end{array}$} & Ligation & 120 & 21.8 \\
\cline { 2 - 4 } & Natural & 204 & 37.1 \\
\hline & Oral contraceptive & 58 & 56.4 \\
\hline pills & IUCD & 86 & 10.5 \\
\cline { 2 - 4 } & Injectable & 67 & 1.3 \\
\hline
\end{tabular}

We noted that despite majority of women having received at least a basic schooling, knowledge of EC remains poor. An important observation of the study was that although $45.8 \%$ women claimed to have received regular contraceptive advice from health personnel, only $13.6 \%$ women had received information of EC from their care providers. Singh et al found the awareness of EC high among doctors; however, most of them were unable to write a correct prescription for the same. ${ }^{7}$ Tripathi et al observed that EC knowledge was low in Indian general population and paramedical workers; although doctors are aware of EC, its precise knowledge was lacking. They proposed prescription writing practices for EC amongst doctors as part of their training. ${ }^{8}$ Globally, many studies have revealed that a poor knowledge of doctors is responsible for lack of EC services to women who need them. ${ }^{9,10}$ This lack of knowledge of medical professionals may also reflect upon the type of counselling they offer. Baveja et al observed that majority of women could make an informed choice regarding contraception provided they had access to correct and balanced information. ${ }^{11}$ Langston et al noted that women appropriately counselled by their doctors were eleven times more likely to use EC in the following year. ${ }^{12}$

Social media is an important method of dissemination of information about EC. In our study, $41.5 \%$ women had seen EC information on television and newspapers. However it is increasingly being realised that the advertisements stress on the accessibility of EC pills and use catch phrases such as 'tension free'. There is lack of emphasis on the fact that these products should be used in emergency situations only. ${ }^{13}$
Table 3: Knowledge of emergency contraception.

\begin{tabular}{|c|c|c|}
\hline \multicolumn{3}{|c|}{ Do you know of EC? } \\
\hline Yes & 190 & $34.5 \%$ \\
\hline No & 360 & $65.5 \%$ \\
\hline \multicolumn{3}{|c|}{ How do you know of EC? $[\mathrm{n}=190]$} \\
\hline Doctor & 26 & $13.68 \%$ \\
\hline Relative/friend & 85 & $44.73 \%$ \\
\hline Mass media & 79 & $41.57 \%$ \\
\hline \multicolumn{3}{|c|}{$\begin{array}{l}\text { Have you ever used emergency contraception? }[\mathrm{n}= \\
\text { 190] }\end{array}$} \\
\hline Yes & 69 & $36.3 \%$ \\
\hline No & 121 & $63.6 \%$ \\
\hline \multicolumn{3}{|c|}{ Who prescribed EC to you? $[\mathrm{n}=69]$} \\
\hline Doctor & 7 & $10.14 \%$ \\
\hline Self & 62 & $89.85 \%$ \\
\hline \multicolumn{3}{|c|}{$\begin{array}{l}\text { Do you know how long after unprotected sex should } \\
\text { emergency contraception be used? }[\mathrm{n}=190]\end{array}$} \\
\hline Within 24 hours & 30 & $15.8 \%$ \\
\hline Within 72 hours & 31 & $16.3 \%$ \\
\hline Don't know & 129 & $67.9 \%$ \\
\hline \multicolumn{3}{|c|}{$\begin{array}{l}\text { What methods can be used for emergency } \\
\text { contraception? }[\mathrm{n}=190]\end{array}$} \\
\hline Pills & 103 & $54.2 \%$ \\
\hline $\mathrm{Cu} \mathrm{T}$ & 01 & $0.5 \%$ \\
\hline Condom & 09 & $4.7 \%$ \\
\hline Don't know & 77 & $40.5 \%$ \\
\hline \multicolumn{3}{|c|}{ How many times have you used EC? } \\
\hline Never & 481 & \\
\hline Once & $21 / 69$ & $30.4 \%$ \\
\hline More than once & $48 / 69$ & $69.5 \%$ \\
\hline \multicolumn{3}{|c|}{$\begin{array}{l}\text { Do you know any side effects of repeated use of EC? } \\
{[n=190]}\end{array}$} \\
\hline Yes & 15 & $7.8 \%$ \\
\hline No & 175 & $92.1 \%$ \\
\hline
\end{tabular}

The knowledge of side effects associated with repeated use of EC was found to be poor in the present study. Amongst women with awareness of EC, only $7.8 \%$ were aware of the side effects. It is important that while mass media is credited with spreading awareness of EC, it is not updating the public with side effects. Most of the women reported over the counter usage of EC and majority had used EC more than once. It needs to be emphasised that while EC is a good method in emergencies, there are associated side effects when used repeatedly, thus it should not be used as a regular method of contraception.

Another important observation in the present study was that awareness of IUCD as a method of emergency contraception was extremely low. This needs to be taken up because besides providing EC, it will also serve as a long acting reversible contraceptive [LARC] and serve as an important tool in curbing unplanned pregnancies. 
Langston et al observed that advance provision of EC to women was not successful in decreasing rates of unintended pregnancy when compared with routine pharmacy access. ${ }^{12}$ In India, despite the over-the-counter availability of EC, there exists rural - urban disparity in its availability. Also there are cost constraints in procurement of EC by lower socio-economic strata. ${ }^{14}$

\section{CONCLUSIONS}

Knowledge regarding EC is low in Delhi despite good education among women in this area. Despite over the counter availability of EC in India, its correct usage is not well known by majority of women. Mass media has increased public awareness of EC but has yet to increase awareness that EC is not a replacement for a regular method of contraception. Medical personnel are disseminating regular contraceptive advice but provision of EC advice is poor. It is best to promote IUCD as EC as it can continue to act as LARC.

Funding: No funding sources Conflict of interest: None declared

Ethical approval: The study was approved by the Institutional Ethics Committee

\section{REFERENCES}

1. Alkhazrajy LA, Hadi AH. Knowledge, attitudes \& practice about EC among sample of women attending primary health care centers in Baghdad. European Journal of Biology and Medical Science Research. 2014;2:1-24.

2. Bartfai G. EC in clinical practice: global perspectives. Int J Gynaecol Obstet 2000; 70:49-58

3. Takkar N, Goel P, Saha PK, Dua D. Contraceptive practices and awareness of EC in educated working women. Indian J Med Sci. 2005;59:143-9.

4. Nigam A, Maheshwari N, Prakash A. Knowledge of EC and Contraceptive Practices: Representative Study from Rural Uttar Pradesh. Indian J Community Med. 2010;35:449-50.
5. Maulik S, Dasgupta A. Knowledge, perceptions and practice of 'family planning' methods in mothers visiting an immunisation clinic of rural Bengal, India. Indian Journal of Medical Specialities. 2013;4:75-80.

6. Palermo T, Bleck J, Westley E. Knowledge and Use of EC: A Multicountry Analysis. Intl Perspect Sex Reprod Health. 2014;40(2):79-86.

7. Singh S, Mittal S, Anandalakshmy PN, Goel V. EC: knowledge and views of doctors in Delhi. Health and Population-Perspectives and Issues. 2002:25(1):4554.

8. Tripathi R, Rathore AM, Sachdeva J. EC: knowledge, attitude and practices among health care providers in North India. J Obstet Gynaecol Res. 2003;29:142-6

9. Langer A, Harper C, Garcia Barrios C, Schiavon R, Heimburger A, Elul B. EC in Mexico City: What Do Health Care Providers and Potential Users Know and Think About It? Contraception. 1999;60(4):233-41.

10. Burton R, Savage W. Knowledge and Use of Postcoital Contraception: A Survey Among Health Professionals in Tower Hamlets; Br. Jr. Gen. Pract.1990;40:326-30.

11. Baveja R, Buckshee K, Das K, Das SK, Hazra MN, Gopalan S. Evaluating contraceptive choice through the method-mix approach. An Indian Council of Medical Research (ICMR) Task Force Study. Contraception. 2000;61:113-9.

12. Langston A. EC: Update and review. Semin Reprod Med. 2010;28:95-102.

13. Dixit R, Marfatia YS. Abstracts from current literature: EC. Indian J Sex Transm Dis. 2010; 31(1):51-3.

14. Sarkar NN. Barriers to EC (EC): Does promoting EC increase risk for contacting sexually transmitted infections, HIV/AIDS? Int $\mathrm{J}$ Clin Pract. 2008;62:1769-75.

Cite this article as: Ahmad A, Nigam A, Elahi AA, Jain R, Batra S. Emergency contraception:

knowledge, attitude and practices among women in South Delhi, India. Int J Reprod Contracept Obstet Gynecol 2016;5:411-4. 